УДК 37.034:338.378

DOI https://doi.org/10.24919/2308-4863/35-1-38

Олеся БОЙВАН,

orcid.org/0000-0002-3512-0315

кандидат педагогічних наук,

старший викладач кафедри теорії і практики перекладу Донецького національного університету імені Василя Стуса (Вінниия, Україна) olesiaboivan@gmail.com

Оксана КОВТУН,

orcid.org/0000-0002-9139-8987 кандидат філологічних наук, старший викладач кафедри теорії і практики перекладу Донецького начіонального університету імені Василя Стуса (Вінниця, Україна) o.kovtun.work@gmail.com

\title{
ПРОБЛЕМА ФОРМУВАННЯ СТУДЕНТА-ГУМАНІСТА В УМОВАХ ДІДЖИТАЛІЗАЦІЇ ОСВІТНЬОГО СЕРЕДОВИЩА
}

У статті акцентується увага на проблемі формування студента-гуманіста в умовах діджиталізації освітнього середовища з урахуванням важливості певних моральних якостей, які, на нашу думку, є основоположними для успішної реалізації задуманого.

Спираючись на теоретичні розвідки та власні спостереження, метою дослідження визначено виявлення певних особистісних, моральних якостей у процесі виховних впливів, щчо є фундаментальними для формування студента-гуманіста в умовах діджиталізації освітнього простору. Нами уточнено дефініції ичих трьох рис (лояльність, самовладання, відповідальність), а також ми вважаємо, щу їх спільною характеристикою риси, які сприяють розвитку гуманності молодої людини. Лояльність - ие моральна риса особистості, щцо характеризується прихильністю та розумінням іншого на основі доброзичливого ставлення до потреб і життєвих позиції оточення з обов'язковою повагою до себе $і$ своїх бажань. Самовладання - моральна якість особистості, щзо забезпечує рівновагу між зовнішніми та внутрішніми чинниками для приборкання надмірності емоцій та імпульсів, шьо сприяє точній оцінці ситуачії і є більшою гарантією успіху у вирішенні тих чи інших проблемних ситуаиій. Відповідальність - це моральна якість особистості, яка виявляється у різноманітних життєвих ситуаціях, де людина здатна проявити старанність і дбайливість у досягненні власних цілей, зважаючи на ситуації та почуття інших.

Переконані в тому, щчо саме емоиійні стани, інтереси, моральні якості структурують гуманність особистості, надаючи иій категорії чітких форм сприйняття й розуміння ї̈ іншими. До того ж вищезгадані структурні елементи студента-гуманіста не можуть існувати незалежно одне від одного; вони взаємопов'язані, чим стимулюють свій подальший розвиток і прогрес.

Практична робота має проводитися паралельно до теоретичної і за допомогою ненав'язливих методів, які мають сильніший вплив на інструментальну сферу особистості, використовуючи при иььому всі можливі переваги циифровізації освітнього середовищза.

Ключові слова: гуманність, студент-гуманіст, діджиталізачія, освітнє середовище, відповідальність, самовладання, лояльність.

Olesia BOIVAN, orcid.org/0000-0002-3512-0315

Candidate of Pedagogical Sciences, Senior Lecturer at the Department of the Theory and Practice of Translation Vasyl Stus Donetsk National University (Vinnytsia, Ukraine) olesiaboivan@gmail.com

Oksana KOVTUN, orcid.org/0000-0002-9139-8987 Candidate of Philological Sciences, Senior Lecturer at the Department of the Theory and Practice of Translation Vasyl Stus Donetsk National University (Vinnytsia,Ukraine) o.kovtun.work@gmail.com 


\section{THE PROBLEM OF FORMATION OF A STUDENT-HUMANIST IN THE DIGITALIZED EDUCATIONAL ENVIRONMENT}

The article focuses on the problem of formation of a student-humanist in the digitalized educational environment, based on the importance of certain moral qualities, which, in our opinion, are fundamental for the successful implementation of the plan.

Taking into consideration the theoretical research and our own observations, the purpose of the article was determinedto determine some certain personal, moral qualities in the process of educational influences that are fundamental for the formation of the student-humanist in the process of digitalization of educational environment. We have clarified the definitions of these three qualities (loyalty, self-control, responsibility) and believe that their common characteristic is that they have certain similar features that contribute to the development of humanity with any young person. Loyalty is a moral quality of a person, characterized by commitment and understanding of others on the basis of a friendly attitude to the needs and life positions of others with a necessary element of respect for himself and his desires. Self-control is a moral quality of personality that provides a balance between external and internal factors to curb the excess emotions and impulses, which contribute to an accurate assessment of the situation and is a greater guarantee of success in solving the problems. Responsibility is a moral quality of a person, which is manifested in various life situations, where a person is able to show diligence and care in achieving his own goals, taking into account the situations and feelings of others.

We are convinced that emotional states, interests, moral qualities structure the humanity of the individual, giving this category clear forms of perception and understanding of it by others. In addition, the above-mentioned structural elements of the student-humanist cannot exist independently, they are interconnected, stimulating their further development and progress.

Practical work should be carried out constantly in parallel with theoretical using the unobtrusive methods that have a stronger impact on the instrumental sphere of personality with all the possible advantages of digitalization of the educational environment.

Key words: humanity, student-humanist, digitalization, educational environment, responsibility, self-control, loyalty.

Постановка проблеми. Сучасний етап досліджень проблеми формування студента-гуманіста характеризується активним пошуком еталонних зразків, що описуються за допомогою різноманітних термінів, понять, категорій і дефініції молодої людини, орієнтації якої спрямовані не тільки на результативність навчально-виховного процесу, а й на інтегральний, глибоко моральний феномен бачення свого єства, що базується на позитивній людській взаємодії. Проблема формування студента-гуманіста є актуальною для навчальновиховного процесу, особливо студентської молоді, від якої залежить майбутнє не тільки країни, а й окремо взятої особистості, яка $\epsilon$ невід'ємним і важливим компонентом морально здорової нації. Наголошуємо на тому факті, що технократизоване сьогодення може стати тригером негативізму в процесі зародження основ гуманності, яка з трендів ніколи не вийде, оскільки є однією з основоположних фундаментальних практик людських стосунків та особливостей нашого співжиття. У нашій науковій розвідці прагнемо підкреслити важливість урівноваження двох понять студентагуманіста та діджиталізації суспільства і показати можливості ефективності взаємодії вище згаданих аспектів. Процес діджиталізації або цифровізації охопив освітнє середовище цілком i повністю й надалі це триватиме, змінюючи форми або темпи. Сьогодні вищому навчальному закладу просто не можна стояти осторонь і спостерігати за процесом, адже він сам $є$ активним учасни- ком і причиною змін, створюючи цілі освітні платформи, проєкти, мультимедійні навчальні програми, тощо. Процес діджиталізації має за основу усвідомлений підхід іiі учасників детальної трансформації навчально-виховного процесу з використанням цифрових технологій. Беручи до уваги такі особливості сучасності, ми переконані, що гуманістичні тенденції у вихованні є незмінними й незамінними, тому їм завжди приділялося достатньо уваги з боку педагогів і науковців.

Аналіз досліджень. Проблема формування студента-гуманіста у вищих навчальних закладах досліджується такими науковцями, як $€$. Березняк, С. Гончаренко, М. Клементович, М. Легкий, I. Наумович, I. Парасюк, I. Підласий, I. Синиця, М. Черпінський, М. Ярмаченко.

Варто зазначити, що вагомий внесок у розвиток гуманістичної педагогіки XX ст. зробили як українські, так і зарубіжні вчені: Я. Корчак, А. Макаренко, С. Русова, В. Сухомлинський та ін. Їх об'єднувало одне спільне бажання - активно боротися за гуманізацію і демократизацію освіти, засуджуючи зубріння, муштру, придушення особистості вихованців. Провідний принцип гуманістичного виховання, за В. Сухомлинським, - зробити дитину щасливою, тому рушійними силами гуманістичного виховання стали довіра і любов до неї, а головним інструментом виховання - добро (Сухомлинська, 1996: 33).

Коротка філософська енциклопедія (Краткая филосовская энциклопедия, 1994) поняття 
«гуманність» визначає так: людяність, людинолюбство, ідеал різноманітних течій гуманізму, як-от головна мета: гармонійний розвиток притаманних людині ціннісних здібностей, почуттів i розуму, вищий розвиток людської культури $\mathrm{i}$ моралі та відповідної їй поведінки у ставленні до інших людей й до усього створіння.

Психологічний тлумачний словник містить таке визначення поняття «гуманність»: це зумовлена моральними нормами і цінностями система установок особистості на соціальні об'єкти (людину, групу, живу істоту), представлена у свідомості співпереживанням і реалізована в спілкуванні й діяльності (в актах сприяння, співучасті та допомоги) (Шапар, 2004: 86 ).

Відомий філософ і богослов П. Абеляр був переконаний у тому, що узгодженість із власною совістю є критерієм моральності особистості. Коли людина йде на порушення моралі, вона (всупереч совісті) глушить іiі голос у собі і викликає зло (Абеляр, 2007). Це суперечить цінностям гуманної людини, яка ставить моральні цінності на перше місце. Він також написав книгу під назвою «Пізнай самого себе», що $\epsilon$ коротким, але влучним шедевром духовності, в якому Абеляр проаналізував поняття гріха і дійшов висновку, що людські вчинки не роблять людину кращою або гіршою в очах Бога, бо справи самі по собі не $\epsilon$ ні добрими, ні поганими (Абеляр, http://bibliyaonline.ru/per). Головне в справах - суть людських намірів, яка стає базовою для народження гуманних основ особистості.

Якщо заглибитися в історію віків і розвиток гуманістичної думки різних епох, то чітко можемо побачити, що гуманістичним ідеям приділялося досить уваги, особливо в часи Відродження, але сучасність 3 елементами цифровізації також сповідує аналогічні явища у вихованні та навчанні молодого покоління, оскільки гуманістична педагогіка - це неповторний та ефективний стиль педагогічного мислення і педагогічних дій, що орієнтується на утвердження гуманістичних ідеалів будь-якої особистості й відповідних їй цінностей і моральних якостей (порядність, тактовність, щирість, товариськість, почуття жалю, стриманість, повага тощо).

3 питань діджиталізації сьогодні проводиться робота у різноманітних напрямах (практична й наукова), оскільки існує чітке розуміння важливості, неминучості та необхідності цього процесу в освітньому середовищі. О. Базелюк, О. Гуменний, Л. Єршова, А. Кононенко, Я. Корнієнко власними науковими розвідками наголошують на широкомасштабному застосуванні цифрових техноло- гій, які суттєво оптимізують навчальний процес. Наголошується, що сутнісними характеристиками цифрових технологій $є$ мобільність, доступність та безкоштовність, зберігання та використання інформації незалежно від місця знаходження, відсутність необхідності оновлення та встановлення програмного забезпечення, оскільки технології «стали хмарними» (6 мегатрендів, http://softline. $\mathrm{ru} / \mathrm{blog} / 6$-megatrendov). Таким чином, одним iз випробувань діджиталізованого освітнього простору $є$ готовність та гнучкість науково-педагогічного працівника до цифрової трансформації навчального процесу. Поняття «діджиталізація» науковці тлумачать як способи приведення будьякого різновиду інформації в цифрову форму 3 використанням цифрових технологій (Купріна, 2016: 259).

Акцентуємо увагу на тому, що у нашому випадку виховного впливу не варто наголошувати на тому, яка в нас стратегія і що ми хочемо побачити в результаті. Педагог, який має за мету формування студента-гуманіста, виступає не керівником цього процесу, а фасилітатором або мотиватором, тобто тим, хто створює необхідні умови для самостійного осмислення й інтересу. Тут доцільно згадати модель маніпуляції, яка може розглядатися як досить ефективний спосіб організації виховного процесу і може бути позитивним засобом розвитку кожного учасника, його самостійності та відповідальності. Основним завданням маніпулятивного виховного впливу є їх прихованість, що зауважувалося багатьма педагогами й науковцями. В. Сухомлинський уважав, що «однією 3 умов високої ефективності педагогічного впливу $є$ обстановка невимушеності цього впливу. Тобто учневі не слід у кожний момент знати, що вчитель його виховує. Виховний намір повинен бути прихований обстановкою дружніх, невимушених взаємин. Зробити свій виховний задум непомітним - один із дуже важливих елементів педагогічної майстерності» (Сухомлинський, 1984: 248).

Мета статті. Отже, базуючись на вищезгаданих теоретичних розвідках та власних спостереженнях, метою статті є визначення певних особистісних, моральних рис у процесі виховних впливів, що $є$ фундаментальними для формування студента-гуманіста в умовах діджиталізації освітнього простору.

Виклад основного матеріалу. У нашій роботі пропонуємо звернути увагу на такі ціннісні, моральні якості, які слід формувати у студента, щоб категорія гуманності не стала йому чужою в умовах цифровізації освітнього середовища, як лояльність, самовладання, відповідальність. 
Загалом, дефініція «цінність» характеризує соціокультурну значущість явищ дійсності, що містяться в ціннісних відносинах, за яких вони визначаються як орієнтири діяльності та поведінки людини за умови сформованої ціннісної свідомості, відносин, установок (Підкасистий, 2002).

Ми ж акцентували свою увагу саме на цих трьох якостях, бо вважаємо їх необхідними для процесу формування студента-гуманіста в умовах діджиталізації освітнього процесу. Особистісні моральні якості нашаровуються на емоційно-душевний стан людини, який $є$ обов'язковим елементом гуманістичної структури, що орієнтує й регулює функції розвитку системи гуманістичних потреб. Важливим педагогічним завданням $є$ викликання у вихованця таких переживань, завдяки яким закріпились би вищезгадані моральні якості особистості. Нами уточнено визначення цих трьох якостей і вважаємо, що лояльність - це моральна якість особистості, що характеризується прихильністю та розумінням іншого на основі доброзичливого ставлення до потреб і життєвих позиції оточення 3 обов'язковим елементом поваги до себе і своїх бажань. 3 іншого боку, видатний ірландський письменник і драматург Дж. Б. Шоу писав про сліпу відданість: «Лояльність - це свобода від необхідності думати». 3 ним важко не погодитися. Дійсно, як правило, беззастережно довіряти чиїмось або судження або кому-небудь 3 авторитетів, виконуючи всі накази, набагато легше і спокійніше, ніж міркувати, зіставляти факти i робити висновки, часом маловтішні (Поняття лояльність, https://real-life.kr.ua/termini). Але у нашому випадку визначення з акцентами на позитивне бачення $\epsilon$ актуальнішим.

Самовладання - моральна якість особистості, що забезпечує рівновагу між зовнішніми та внутрішніми чинниками для приборкання надмірності емоцій та імпульсів, що сприяє точній оцінці ситуації і $\epsilon$ більшою гарантією успіху у вирішенні тих чи інших проблемних ситуацій. Самовладання - це така особлива риса, яка потребує копіткої праці над собою, адже з нею не народжуються, iii розвивають, якщо є прагнення й намір.

На жаль, не у кожного виникає така внутрішня потреба, багато хто, опинившись у зоні дискомфорту, губиться в потоках думок та вчинків і не може морально та фізично впоратися 3 факторами-подразниками, шукаючи наосліп, хаотично, як несвідомі кошенята, вихід із ситуації. У цьому разі проблема залишається, а внутрішні ресурси псуються й просто згорають, тому тут людина може обрати варіант втечі від труднощів. Ми ж прагнемо розвивати таку якість, як самовладання.
Цьому сприяють різноманітні ситуації, що виникають у навчально-виховному процесі. Головним $\epsilon$ те, щоб вчасно їх помітити і вміло використати 3 чітко окресленою виховною метою.

Підготували декілька слушних порад, що допоможуть керувати собою: подумки потрібно заспокоїтися (у кожного власний спосіб), після чого буде легше тверезо міркувати. Зопалу відповівши на зло тією ж монетою, собі плюсів не додаси i не полегшиш свій стан; вияви дипломатію, адже це незамінна майстерність побудови себе й стосунків з іншими, спробуй зрозуміти іншого, вияви емпатію, стань на його місце, якщо прояснити для себе всі обставини, то пробачати чужі помилки легше, матимеш внутрішній спокій та гармонію; наступна порада полягає в тому, щоб шукати допомоги в інших людей, які є близькими по духу i, безсумнівно, вислухають і вирішать ситуацію.

Відповідальність - це моральна якість особистості, яка виявляється у різноманітних життєвих ситуаціях, де людина здатна виявити старанність i дбайливість у досягненні власних цілей, зважаючи на ситуації та почуття інших. Відповідальність як етична категорія має декілька значень: за що людина відповідає та перед ким вона відповідає. У цьому аспекті можна виділити відповідальність людини перед собою (здійснюючи вибір «вибираю сам себе» та несу відповідальність), відповідальність за конкретні вчинки перед іншими людьми, відповідальність перед людством і світом (відповідаю за все). Бути відповідальним думати про інших і про наслідки своїх учинків (чи не принесуть вони шкоди людям) (Відповідальність, https://pidru4niki.com).

Такі моральні якості стають у нагоді, коли трапляються зміни в освітньому просторі, як це трапилося 2020 року, коли всі категорії населення мали підлаштовуватися під вимоги карантину. Молоді люди, які є відповідальними, лояльними, 3 достатнім рівнем самовладання змогли без нарікань та проблем переключитись на такий незвичний до цього онлайн формат. У багатьох покращились результати й продуктивність праці.

За нашими спостереженнями вищі навчальні заклади цьогоріч (у періоди локдаунів для дистанційного навчання) найчастіше користувалися такими платформами, як Zoom, Skype, Viber, електронна пошта, Google Classroom та інше. Загалом, робота щодо впровадження більшої кількості цифрових технологій, які були б доступними для всіх учасників освітнього процесу, триває. Так, наприклад, ДонНУ імені Василя Стуса зумів підписати угоди 3 «Майкрософт» щодо безкоштовного використання Microsoft Teams для 
налагодження онлайн-занять усім співробітникам університету. Цей зручний сервіс дозволяє таке: організовувати онлайн-заняття, створювати віртуальні класи, влаштовувати засідання вчених рад або ж КТК, створювати закриті чати для спілкування; організовувати відеоконференції з підключенням до 300 учасників (зустріч із ректором для нагородження студентства), створювати журнали успішності; здійснювати оцінювання, планування завдань, контроль над їх виконанням.

У такій формі (Скайп, Вайбер, Телеграм, Microsoft Teams) велася робота зі студентами для нашого практичного дослідження. Студентам було запропоноване анкетування (автор О.С. Бойван), де вони мали дати відповідь на поставлені запитання. Студенти другого курсу факультету іноземних мов, кафедри теорії і практики перекладу були респондентами в цьому опитуванні. Загальна кількість - 38 .

\section{Анкета для студентів}

Друже, пропонуємо твоій увазі анкету на визначення твого розуміння категорії гуманності, яке місце у твоєму житті посідає це поняття.

Керуючись власним життєвим досвідом, намагайся давати відверті та щирі відповіді свого бачення цієї проблеми.

1. Поставте у порядку значушості для Вас такі людські якості: лояльність, відповідальність, самовладання?

1.

2.

3.

2. Чи радієте, коли досягають успіху інші?

A) Так

Б) $\mathrm{Hi}$

В) Інколи

3. Ви допоможете іншому безкорисливо?

А) Так

Б) $\mathrm{Hi}$

В) Інколи

4. Чи погоджуєтесь Ви 3 твердженням «Любити - собі шкодити».
A) Так
Б) $\mathrm{Hi}$
В) Важко відповісти

5. Як Ви думаєте, чи простіше і легше лояльній людині будувати стосунки у новому колективі?
А)Так
Б) $\mathrm{Hi}$
В) Важко відповісти
A) Так
Б) $\mathrm{Hi}$
В) Важко відповісти

6. Ви щиро співчуваєте чужому горю?
7. Чи вважаєте Ви себе гуманною людиною?
A) Так
Б) $\mathrm{Hi}$
В) Важко відповісти

8. У Вашому вжитку багато нецензурних слів?

A) Так

Б) $\mathrm{Hi}$

В) Не дуже

9. Як Ви вважаєте, вірність - пережиток минулого?

A) Так

Б) $\mathrm{Hi}$

В) Залежно від ситуації

10. Чи прагнете Ви до самовдосконалення? Чи сприяють цьому сучасні технології?

А) Так

Б) $\mathrm{Hi}$

В) Важко сказати

11. Наведіть приклади гуманної поведінки Ваших одногрупників.

12. Назвіть приклади антигуманної поведінки Ваших одногрупників.

Аналізуючи відповіді респондентів, варто вказати на загальну позитивну тенденцію сприйняття й розуміння категорії гуманності як необхідного складника інструментальної сфери кожного. Студентами було наведено багато прикладів гуманної поведінки, яка виявлялась у розумінні, підтримці, допомозі, сприянні, тощо. Але було й декілька негативних історій (обман, хитрування, замовчування). Усі студенти стверджували у своїх анкетах, що їм зовсім не важко допомагати іншим безкорисливо, від цього з'являється почуття радості й душевного спокою, а також більшість (25 студентів) радіє з того, коли хтось досягає успіху, частина респондентів уточнили (13 студентів), що досягнення успіху іншими стимулює їх до більш активних дій. Абсолютно всі вихованці (38 студентів) відповіли «так» на запитання про самовдосконалення і сприяння цьому сучасних технологій. У наш час це робити легко, але слід виявити бажання, тоді особистісне зростання буде швидшим, кращим й ефективнішим. Щодо нецензурних слів, то результати такі 10 студентів зовсім не вживають нецензурних слів, 21 під впливом емоційно-негативних факторів, 7 утримались від відповіді (можливо, тому, що не змогли проаналізувати питання і визначити, яка ж кількість нецензурних слів є великою, посередньою і зовсім низькою). На питання № 5 студенти також дали неоднозначну відповідь, наголосивши: якщо лояльність ближча до дипломатії, тоді $з$ такою моральною якістю легко вживатися 3 колективом, але якщо лояльність ближча до 
страху і постійної поступливості, тоді це ніяк не допоможе нікому мати толерантні і дружні взаємини в групі. 23 респонденти вважають себе гуманними людьми. Думаємо, це гарний результат нашого моніторингу.

Також було цікаво читати й аналізувати інтерв' ювання студентів (автор О.С. Бойван), яке тісно переплітається з темою нашої статті.

Інтерв'ювання студентів

1. Бути гуманною людиною - це не тільки виявляти такт та лояльність до людей, а й........

2. Гуманна людина вміс не тільки слухати, а й

3. Гуманним може бути кожен, якщо.

4. Для того, щоб розвинути в собі якості гуманної людини, треба.

5. Назвіть дисципліни, які найбільше сприяють формуванню гуманності.

Інтерв'ювання студентів відбувалося в онлайнбесіді за допомогою скайп-конференції; результати фіксувались. На перше питання студенти давали різноманітні розгорнуті відповіді, ключовим моментом яких були моральні якості розуміння, підтримки, поваги, толерантності, стриманості, відкритості, емпатії тощо. Респонденти переконані, що гуманна людина вміє не тільки слухати, а й діяти, тобто підтримувати, відгукуватись на проблеми. Гуманним може бути кожен, якщо цього хотіти і розуміти наслідки. Студенти правильно розуміють категорію гуманності. Це не означає дивитися на все навколо в «рожевих окулярах», а це реальне випробування і «муштра» характеру, тому що важко бути гуманним, коли тебе не розуміють, ображають, недооцінюють. У таких ситуаціях потрібно знаходити в собі багато внутрішньої сили, щоб подолати трудність, зберігши «людську подобу». Наступне питання було пов'язане 3 дилемою розкриття й розвитку якості гуманної людини (що ж для цього потрібно?). Всі студенти апелювали до такого факту: це бажання; якщо не хочеш, то й не відчуваєш такої необхідності, значить тобі комфортно жити за іншим принципом. П'яте питання охоплювало навчальний спектр і ми просили назвати дисципліни, які найбільше сприяють формуванню гуманності. Більшість студентів (22) переконані, що нема різниці, яка дисципліна, а все залежить від світобачення викладача, його стосунків із групою. Гуманний педагог, залучаючи вихованців до знань, одночасно передає їм свій характер, настрій, емоції. Якщо студент через певні причини має страх перед викладачем, то навчання втрачає для нього свою цінність, оскільки такий внутрішній дискомфорт не $\epsilon$ сприятливим середовищем для навчально-виховного процесу.

У процесі інтерв'ювання студенти все більше замислювалися над необхідністю такої риси, як гуманність, не дивлячись на те, що це непросте рішення приймалося у процесі частих суперечок, непогоджень, сумнівів, але більшість все-таки визнала той факт, що саме самовладання, особиста відповідальність, лояльність тощо завжди «рятують світ».

Також було запропоновано студентам написати коротенькі твори-роздуми 3 тематики гуманності й формування гуманіста. Деякі 3 них були відібрані як приклади. Зміст творчих робіт студентів показав досить позитивні зрушення в розумінні й усвідомленні важливості, цінності та необхідності формування гуманіста в технократизованому суспільстві.

Чи легко бути гуманним у швидкісному темпі сьогодення?

Відразу ж можна відповісти: «Нi! Це дуже важко».

Бути добрим і ввічливим, коли тобі боляче наступили на ногу в автобусі та ще й на додачу облаяли, бо став або сів не у тому місці, бути радісним i оптимістичним, коли навкруги так багато проблем і турбот, а особливо тоді, коли потрібно підготуватися до контрольної 3 «улюбленого» предмета, бути терпимим і вміти пробачати, коли тебе осуджують, не приймають, не розуміють...

Увесь цей набір і ще багато іншого заважають ставати гуманнішим, тому що мусиш «гострити зуби» для того, щоб тебе не загризли інші, для вдалого спілкування з людьми.

Пишу подібні речі, а самій стає страшно: невже усе так погано?

Але, згадуючи про вічні почуття (любов, милосердя, великодушність, ніжність, прощення), розумію, що без усього цього світлого уже б не існувало життя на цій Землі і не було б мене, такої доброї, хорошої, милої. Радію думці, що неписані духовні цінності мають небачену силу. Часом ми ï ігноруємо, заперечуємо, як щойно зробила я.

Чи існують гуманні стосунки у групі, на якій вони стадії розвитку?

На мою думку, гуманні стосунки у нашій групі $\epsilon$ i будуть, а доказом для цього слугують наші посмішки зранку, коли приходимо в аудиторію і вітаємося одне з одним, наша підтримка, коли у когось 3 одногрупників виникають проблеми 3 навчанням або особистого характеру, про існування гуманних стосунків свідчить рівень довіри, тому що часто ділишся своїми таємницями, пере- 
живаннями, радістю саме 3 друзями по студентській лаві.

Мені особисто дуже подобається бути «трансформером», коли дорослішаєш і перетворюєшся на більш досконалу особистість, особливо у духовному розумінні, адже намагаєшся бути розсудливим, терплячішим, добрішим. Але високотехнічність «трансформера» залежить від самої людини, якщо у неї є сильне бажання і воля ставати позитивною, виховуючи в собі прекрасну внутрішню гармонію, то вона, безсумнівно, досягне високих результатів.

На жаль, кожен день переповнений різними перешкодами, що стоять на заваді нашим гармонійним стосункам: сварки, непорозуміння, поганий настрій, репресивність тощо. Звичайно, це можна пояснити і кількістю зібраних різних людей в одній групі, і тим, що кожен 3 нас має «свою правду» стосовно тієї чи іншої ситуації.

Але це можна пережити, адже ми хоч і сваримося, але швидко «відходимо» і все-таки вміємо робити висновки, аналізувати помилки і вибачатися.

\section{Мої стосунки з іншими людьми.}

Мої стосунки $з$ іншими людьми складаються по-різному: трапляються конфлікти, але часом я навіть перший роблю крок назустріч, щоб 3'ясувати причину непорозумінь. Я намагаюсь бути чесним у взаєминах 3 іншими людьми, але помічаю те, що моя чесність і відвертість часто мені заважає, спричиняючи різноманітні проблеми, такі як сварки, образи, недомовленості і т.д. Я це пояснюю тим, що не люблю лицемірства i брехні, тому звик казати усім правду в очі, а не за спиною. Нерідко ця правда може бути неприєм- ною, тому не всьому оточенню подібні мої вчинки подобаються, ось чому деякі мої знайомі просто уникають спілкування зі мною.

Я не знаю, чи є правильною моя позиція у житті. Ми говоримо про гуманність, але я іï розумію по-своєму: «Не той друг, хто медом маже, а той, хто правду каже». Я належу до категорії людей, які в будь-якому разі скажуть правду, якою б прикрою і болісною вона не була.

Це не є гуманним? А брехня гуманна? Можливо! Але я й надалі дотримуватимусь свого принципу в житті, тому що вмію жаліти, пробачати, любити і чекаю цього від інших.

Висновки. Отже, якщо підсумувати все вищесказане, то потрібно зауважите те, що гуманність як особистісна риса завжди була і є необхідним складником прогресу й здобутків людства. Робота 3 молоддю має перспективи і дає певні шанси щось змінити, вдосконалити, набути. Опанування системи вищеописаних гуманістичних рис (лояльність, самовладання, відповідальність) озброює студентів знаннями про важливі й значущі ознаки гуманних якостей особистості в умовах діджиталізації освітнього середовища, дозволяє відкривати свої переваги та моральність інших. Студентгуманіст проходить у своєму формуванні довгий шлях. Не завжди він є успішним та вдалим, але планомірне й покрокове становлення гуманної особистості робить ії здатною осмислювати суть гуманності, визнавати іiі необхідність. Ефективність виховних впливів із боку педагога залежить від того, наскільки безперервним і поступальним $\epsilon$ цей процес, оскільки реалізується через ті цінності, які вже в певній мірі сформовані в єстві молодої людини.

\section{СПИСОК ВИКОРИСТАНИХ ДЖЕРЕЛ}

1. Абеляр П. Історія моїх страждань. Львів : Літопис, 2007. 736 с.

2. Визначення поняття лояльність. URL: https://real-life.kr.ua/termini/viznachennia-poniattia-loialnist (дата звернення: 04.02.2021).

3. Козлов Н. I. Що таке відповідальність і відповідальний підхід. URL: http://psychologis.com.ua/chto_takoe_ otvetstvennost_i_otvetstvennyy_podhod.htm (дата звернення: 04.02.2021).

4. Краткая философская энциклопедия. Москва : Прогресс, 1994. 576 с.

5. Куприна К. А. Диджитализация: понятие, предпосылки возникновения и сферы применения. Becтник научных конференщий. Тамбов, 2016. № 5-5 (9). С. 259-262.

6. Педагогика: учебное пособие для студентов педагогических вузов и педагогических колледжей. Москва : Педагогическое общество России, 2002. 426 с.

7. Сухомлинский В. О. Сто порад учителеві : у 5 т. Київ : Рад. школа, 1984. Т. 2. 254 с.

8. Сухомлинська О. В. Френе і В. Сухомлинський: спільне і відмінне у вихованні. Шлях освіти. 1996. C. $30-35$.

9. Шапар В. Б. Психологічний тлумачний словник. Харків : Прапор, 2004. 640 с.

10. П’єр Абеляр. Біографія й філософія. URL: http://bibliya-online.ru/per-abelyar-biografiya-i-filosofiya/ (дата звернення: 04.02.2021).

11. 6 мегатрендов - будущее цифровой экономики. URL: http://softline.ru/blog/6-megatrendov-buduschee-tsifrovoyekonomiki (дата звернення: 04.02.2021).

12. The Global Information Technology Report. Growth and Jobs in a Hyperconnected World. URL : www.weforum.org/ gitr_version.pdf (дата звернення: 04.02.2021). 


\section{REFERENCES}

1. Abeliar P. Istoriia moikh strazhdan. [The story of my suffering]. Lviv: Litopys, 2007. 736 p. [in Ukrainian].

2. Vyznachennia poniattia loialnist. [Definition: loyalty]. URL: https://real-life.kr.ua/termini/viznachennia-poniattialoialnist [in Ukrainian]. (appeal date: 04.02.2021).

3. Kozlov N. I. Shcho take vidpovidalnist i vidpovidalnyi pidkhid. [What is responsibility and responsible approach]. URL: http://psychologis.com.ua/chto_takoe_otvetstvennost_i_otvetstvennyy_podhod.htm [in Ukrainian]. (appeal date: 04.02.2021).

4. Kratkaya filosofskaya entsiklopediya. [Brief philosophical encyclopedia]. M. : Progress, 1994. 576 p. [in Russian].

5. Kuprina K. A. "Didzhitalizatsiya: ponyatie, predposyilki vozniknoveniya i sferyi primeneniya". [Digitalization: concept, background and scope]. Scientific conference bulletin. 2016, № 5-5 (9), pp. 259-262. [in Russian].

6. Pedagogika: uchebnoe posobie dlya studentov pedagogicheskih vuzov i pedagogicheskih kolledzhey. [Pedagogy: a textbook for students of pedagogical universities and pedagogical colleges]. M. : Pedagogicheskoe obschestvo Rossii, 2002. 426 p. [in Russian].

7. Sukhomlynskyi V. O. Sto porad uchytelevi [One hundred tips for a teacher] : Selected works in 5 volumes. K.: Rad. shkola, 1984. T. 2. 254 p. [in Ukrainian].

8. Sukhomlynska O. V. Frene i V. Sukhomlynskyi: spilne i vidminne u vykhovanni. [V. Frene and V. Sukhomlinsky: common and different in education]. The path of education. 1996, № 2, pp. 30-35. [in Ukrainian].

9. Shapar V. B. Psykholohichnyi tlumachnyi slovnyk. [Psychological explanatory dictionary]. Kh.: Prapor, 2004. 640 p. [in Ukrainian].

10. Pier Abeliar. Biohrafiia y filosofiia. [Pierre Abelard. Biography and philosophy]. URL: http://bibliya-online.ru/perabelyar-biografiya-i-filosofiya/ in Ukrainian]. (appeal date: 04.02.2021).

11. 6 megatrendov - buduschee tsifrovoy ekonomiki. [6 megatrends - the future of the digital economy]. URL: http://softline.ru/blog/6-megatrendov-buduschee-tsifrovoy-ekonomiki [in Russian]. (appeal date: 04.02.2021).

12. The Global Information Technology Report. Growth and Jobs in a Hyperconnected World. URL : www.weforum.org/ gitr_version.pdf (appeal date: 04.02.2021). 